\title{
Biodegradation of isoproturon by Pseudoxanthomonas sp. isolated from herbicide-treated wheat fields of Tarai agro-ecosystem, Pantnagar
}

\author{
Krishna Giri ${ }^{1} \cdot$ Shailseh Pandey ${ }^{1} \cdot$ Rajesh Kumar $^{1}$ J. P. N. Rai ${ }^{2}$
}

Received: 16 June 2016/ Accepted: 24 August 2016/Published online: 2 September 2016

(c) The Author(s) 2016. This article is published with open access at Springerlink.com

\begin{abstract}
A gram-negative, rod-shaped, isoproturon (IPU) utilizing bacterium was isolated from herbicide-applied wheat fields of Tarai agro-ecosystem, Pantnagar. The phylogenetic sequence analysis based on 16S rRNA sequence revealed that the isolate could be a distinct species within the genus Pseudomonas. The isolate was a close relative of Pseudoxanthomonas japonensis (95\% similarity) and designated as $\mathrm{K} 2$. The bacterial isolate showed positive reaction for oxidase, catalase, and 20 carbohydrates using KB009 Part A and B HiCarbohydrate ${ }^{\mathrm{TM}}$ Kit. Degradation experiments were conducted using $200 \mathrm{mg}^{-1}$ initial IPU as a source of carbon at different $\mathrm{pH}$ and temperatures. Maximum IPU degradation by K2 was observed at $\mathrm{pH} 7.0$ and $30^{\circ} \mathrm{C}$, while least degradation at $6.5 \mathrm{pH}$ and $25^{\circ} \mathrm{C}$. Addition of dextrose along with IPU as an auxiliary carbon source increased IPU degradation by $4.72 \%$, as compared to the IPU degradation without dextrose under optimum conditions. 4-isopropylaniline was detected as a degradation by-product in the medium. The present study demonstrated the IPU metabolizing capacity of a novel bacterial isolate $\mathrm{K} 2$ that can be a better choice for the remediation of IPU-contaminated sites.
\end{abstract}

Keywords Phenylurea · Herbicide · Isoproturon · Biodegradation $\cdot$ Pseudoxanthomonas

Krishna Giri

krishna.goswami87@gmail.com

Rain Forest Research Institute, Jorhat, Assam 785 001, India

2 G. B. Pant University of Agriculture and Technology, Pantnagar 263145, India

\section{Introduction}

Isoproturon is an extensively used phenylurea herbicides for control of pre- or post-emergence broad-leaved weeds in cotton, fruits and cereal production. (Sorensen et al. 2003). Ecotoxicological data indicate that IPU and its byproducts are harmful to aquatic environments (Widenfalk et al. 2008; Vallotton et al. 2009), and carcinogenic to humans and animals (Hoshiya et al. 1993; Behera and Bhunya 1990). Moreover, extensive use of IPU has been considered as a severe water pollution threat near agricultural catchments in various parts of the world, exceeding the $0.1 \mu \mathrm{g} \mathrm{l}^{-1}$ limits of European Commission (Spliid and Koppen 1998; Muller et al. 2002). Therefore, the use of IPU has been banned or severely restricted in some countries since 2003; however, it is still being used as a potent herbicide in several countries, including India.

Microbial degradation of pesticides in the environment is a reliable, cost effective and eco-friendly remediation technique (Hussain et al. 2011). A variety of IPU degrading soil micro-flora has been recently isolated from contaminated sites in various parts of the world (Badawi et al. 2009; Hussain et al. 2009; Sun et al. 2009). Fortunately, Sphingomonas sp., Methylopila sp., Sphingobium sp. and Pseudomonas aeruginosa strain JS-11 were found promising for complete IPU mineralization (Sorensen et al. 2001; El-Sebai et al. 2004; Sun et al. 2009; Dwivedi et al. 2011). Interestingly, addition of auxiliary carbon source in the medium or pesticide contaminated sites can stimulate microbial growth and significantly enhance the degradation rates of complex organic pollutants (Scow and Hicks 2005). Biostimulation involves the addition of adequate nutrients in the medium to enhance pesticide degradation potential of native microbes (Couto et al. 2010) or to promote cometabolism (De Lorenzo 2008). Biostimulation is one of the major strategies, which 
has been implemented for the bioremediation of a wide variety of xenobiotics (Kadian et al. 2008; Giri et al. 2015). Although the microbial communities existing in contaminated sites harbour the pesticide catabolising genes and enzymes, lack of electron acceptors or donors, nutrient availability or delayed stimulation of the metabolic pathways essential for degradation acts as limiting factors for pesticide degradation. Under such circumstances, addition of supplementary nutrients or readily available carbon source enhances the degradation of the toxic materials (Cosgrove et al. 2010; Kanissery and Sims 2011).

Uttarakhand, the 27th state of India, is an agrarian state with three-fourth of its total population depending on agriculture. Tarai agro-ecosystem is the major food production zone of Uttarakhand; therefore, pesticide application is also high in this region. Heavy pesticide application poses deleterious effect on non-target beneficial microorganisms, humans and other life forms. Further, ground and surface water contamination, and development of pesticide resistance are some major risks associated with pesticide use. An official survey conducted by Government of India in 2005-06 and 2009-10 indicates that IPU is among the most consumed pesticide in the country (http://www. pesticideinfo.org, retrieved on 24.06.2015 at 9.55 am).

In view of the facts described above, the present investigation aimed to test the IPU degradation potential of a native bacterial isolate that was recovered from IPUcontaminated field.

\section{Materials and methods}

\section{Chemicals and reagents}

Analytical grade IPU and its major metabolites were procured from Sigma Aldrich, USA. All other essential chemicals and microbiological media used in various experiments were of analytical grade and purchased from Himedia Laboratories, India.

\section{Soil sample collection}

IPU-treated composite soil samples at 0-15 cm depth were collected from Norman E. Borlaug Crop Research Centre, Pantnagar, India $\left(29.0210^{\circ} \mathrm{N}, 79.4897^{\circ} \mathrm{E}\right.$ and $344 \mathrm{~m}$ (msl). The soil samples were kept in a refrigerator at $4{ }^{\circ} \mathrm{C}$ till bacterial isolations.

\section{Isolation and identification of IPU degrading bacteria}

IPU degrading bacterium was isolated using enrichment culture method, where concentration of IPU was gradually increased from 50 to $200 \mathrm{mg} \mathrm{l}^{-1}$ in $100 \mathrm{ml}$ mineral salt broth medium. The flasks were incubated in an orbital shaker at 150 revolutions per minute (rpm) and $30{ }^{\circ} \mathrm{C}$. After 5 subcultures, $1.0 \mathrm{ml}$ culture was inoculated in mineral salt agar plates spiked with $200 \mathrm{mg} \mathrm{l}^{-1}$ IPU for the isolation of bacteria. After an incubation of $72 \mathrm{~h}$ at $30{ }^{\circ} \mathrm{C}$, bacterial colonies were appeared on the Petri plates. Single colonies were picked and mass multiplied for degradation studies. The isolate was designated as $\mathrm{K} 2$ and identified on the basis of morphological, biochemical and 16S rRNA partial gene sequence analysis.

\section{Determination of minimum inhibitory concentration (MIC)}

MIC for bacterial growth was determined using 50, 100, 150, 200, 300, 350 and $400 \mathrm{mg} \mathrm{l}^{-1}$ IPU containing mineral salt agar plates after $72 \mathrm{~h}$ of incubation at $30^{\circ} \mathrm{C}$.

\section{Biodegradation of IPU}

Biodegradation of IPU was studied at three different $\mathrm{pH}$ $(6.5,7.0,7.5)$ and temperatures $\left(25,30,35^{\circ} \mathrm{C}\right)$, for 20 days. The flasks containing mineral salt medium and $200 \mathrm{mg} \mathrm{l}^{-1}$ IPU were inoculated with $1 \mathrm{ml}$ of bacterial culture $\left(\mathrm{OD}_{600}=1.0\right)$. The inoculated flasks were then incubated in an orbital shaker at desired temperature and at $150 \mathrm{rpm}$. Samples were withdrawn aseptically after 5, 10, 15 and 20 days of incubation for determination of residual IPU and its metabolites in the medium.

IPU mineralization potential of bacterial isolate was further assessed by adding $0.5 \mathrm{~g} \mathrm{l}^{-1}$ dextrose as an auxiliary carbon source in the medium. The flasks were incubated under optimized conditions, i.e., $7.0 \mathrm{pH}$ and $30^{\circ} \mathrm{C}$ for 20 days at $150 \mathrm{rpm}$. Samples were withdrawn after 5, 10, 15 and 20 days incubation to determine the residual IPU and its metabolites in the medium.

Residual IPU and its metabolites were extracted and processed using the previously described methodology (Giri et al. 2015). The IPU extracts were then analyzed using Dionex HPLC equipped with auto sampler and Acclaim 120, $\mathrm{C}_{18} 5 \mu \mathrm{m} 4.6 \times 250 \mathrm{~mm}$ column. Samples were eluted using acetonitrile and water $(75: 25 \mathrm{v} / \mathrm{v})$ at a flow rate of $1 \mathrm{ml} \mathrm{min}^{-1}$. The solutes were detected using UV detector at $243 \mathrm{~nm}$. The HPLC analysis was performed at room temperature under isocratic conditions in the Department of Fishery Biology, G.B. Pant University of Agriculture and Technology, Pantnagar, India.

\section{Statistical analysis}

Experimental data were analyzed using MS Excel worksheet for calculation of means and standard errors. Analysis 
of variance ANOVA was carried out using SPSS 16 statistical software.

\section{Results and discussion}

\section{Isolation and identification of IPU degrading bacterial strain}

Enrichment culture method was used to isolate IPU degrading bacterial isolate from herbicide-applied wheat fields. The isolate was small rod-shaped, gram-negative, aerobic, non-spore forming bacterium and designated as $\mathrm{K} 2$. K2 was tested for substrates utilization (24 carbohydrates as carbon source and 2 enzymes, viz. oxidase and catalase) to study its metabolizing abilities using KB009 part $\mathrm{A}$ and $\mathrm{B}$ HiCarbohydrate ${ }^{\mathrm{TM}}$ Kit. These tests were based on the principle of substrate utilization and $\mathrm{pH}$ change. The isolate showed positive reaction for oxidase, catalase and 20 carbohydrates (Table 1). 16S rRNA partial gene sequence analysis was used to identify the bacterial isolate. Homology search using BLAST revealed $95 \%$ congruence of this sequence with $16 \mathrm{~S}$ rRNA gene sequence of Pseudoxanthomonas japonensis (GenBank Accession No. NBRC101033). Phylogenetic tree constructed using Mole-Blast showed close relationship of this bacterial isolate (Genbank accession number KF279695) with Pseudoxanthomonas japonensis isolates (Fig. 1), Based on the bacterial growth on mineral salt agar plates supplemented with IPU as a source of carbon at different concentrations, $350 \mathrm{mg} \mathrm{l}^{-1}$ IPU was recorded as the minimum inhibitory concentration for its growth.

Table 1 Biochemical characteristics of IPU degrading bacterial isolate

\begin{tabular}{llll}
\hline Part A (KB009) & Result & Part B (KB009) & Results \\
\hline Lactose & + & Inulin & + \\
Xylose & + & Sodium gluconate & - \\
Maltose & + & Glycerol & - \\
Fructose & + & Salicin & + \\
Dextrose & + & Glucosamine & + \\
Galactose & + & Dulcitol & + \\
Raffinose & + & Inositol & + \\
Trehalose & + & Sorbitol & + \\
Melibiose & + & Mannitol & + \\
Sucrose & + & Adonitol & + \\
L-Arabinose & - & $\alpha$-Methyl-D-Glucoside & + \\
Mannose & + & Ribose & - \\
Catalase & + & Oxidase & + \\
\hline
\end{tabular}

+ positive, - negative test
Effect of pH and temperature on biodegradation of IPU

The effect of $\mathrm{pH}$ and temperature on the IPU degrading potential of $\mathrm{K} 2$ was studied for 20 days. Both the factors showed strong effect on IPU degradation kinetics of $\mathrm{K} 2$ in broth medium. Initially IPU degradation was slow in all the $\mathrm{pH}$ and temperature ranges. After 10 days of incubation, it was increased significantly. IPU degradation by $\mathrm{K} 2$ at $25^{\circ} \mathrm{C}$ and $\mathrm{pH}$ 6.5, 7.0, and 7.5 was $139.34 \pm 0.20$, $146.68 \pm 0.60$ and $143.19 \pm 0.37 \mathrm{mg} \mathrm{l}^{-1}$, respectively (Table 2). After 20 days of incubation, maximum, i.e., $165.73 \pm 0.59 \mathrm{mg} \mathrm{l}^{-1}$ IPU degradation was observed at pH 7.0 and $30{ }^{\circ} \mathrm{C}$. At $\mathrm{pH} 7.5$ and 6.5, degradation was $154.89 \pm 0.51$ and $153.13 \pm 0.36 \mathrm{mg}^{-1}$, respectively (Table 3). However, IPU degradation at $35{ }^{\circ} \mathrm{C}$ and $\mathrm{pH} 6.5$, 7.0 , and 7.5 was $146.25 \pm 0.22,157.63 \pm 0.39$ and $149.85 \pm 0.53 \mathrm{mg} \mathrm{l}^{-1}$, respectively (Table 4). Biodegradation of IPU in control flasks was far less than the inoculated flasks. IPU degradation by $\mathrm{K} 2$ at all the temperatures and $\mathrm{pH}$ values varied significantly $(P<0.05)$ with maximum degradation at neutral $\mathrm{pH}$ and $30{ }^{\circ} \mathrm{C}$.

The cumulative effect of $\mathrm{pH}$ and temperature on IPU biodegradation was assessed under laboratory conditions and maximum biodegradation of IPU was observed at $30{ }^{\circ} \mathrm{C}$ and $7.0 \mathrm{pH}$ followed by $35^{\circ} \mathrm{C}$ and $\mathrm{pH}$ 7.5. However, least degradation was observed at $25{ }^{\circ} \mathrm{C}$ and $\mathrm{pH}$ 6.5. IPU biodegradation was increased with increasing incubation time (Tables 2, 3, 4). Two factorial CRD analysis of experimental data revealed that IPU degradation by $\mathrm{K} 2$ varied significantly $(P<0.05)$ in all the $\mathrm{pH}$ and temperature regimes as compared to the uninoculated control. IPU degradation at $\mathrm{pH} 7.0$ and $30{ }^{\circ} \mathrm{C}$ varied significantly $(P<0.05)$ than that of $\mathrm{pH} 6.5$ and 7.5 , but no significant difference in the IPU degradation was observed at $\mathrm{pH} 6.5$ and 7.5. Similarly, IPU degradation at 35 and $25^{\circ} \mathrm{C}$ varied very less with no significant difference. Statistical analysis confirmed that degradation of IPU was strongly influenced by $\mathrm{pH}$ and temperature. IPU degradation at $\mathrm{pH} 7.0$ and $30{ }^{\circ} \mathrm{C}$ was significantly $(P<0.05)$ higher as compared to other $\mathrm{pH}$ and temperatures. Therefore, $\mathrm{pH} 7.0$ and $30{ }^{\circ} \mathrm{C}$ were observed as the optimum conditions for the IPU degrading capacity of K2. 4-isopropylaniline was detected as degradation by-product in the medium (Table 5).

Biodegradation of IPU has already been studied in several soils repeatedly treated with IPU (Sorensen et al. 2001; Bending et al. 2003; El-Sebai et al. 2005, 2007). Bacterial metabolism of IPU and related phenylurea herbicides is one of the most reliable, cost effective and ecofriendly methods for reducing environmental burdens (Pieuchot et al. 1996; Hussain et al. 2011). Since several bacteria have been reported to have the phenylurea herbicides degrading ability (Dejonghe et al. 2003; El-Sebai 
Fig. 1 Phylogenetic tree based on MUSCLE multiple alignments computed for MoleBLAST

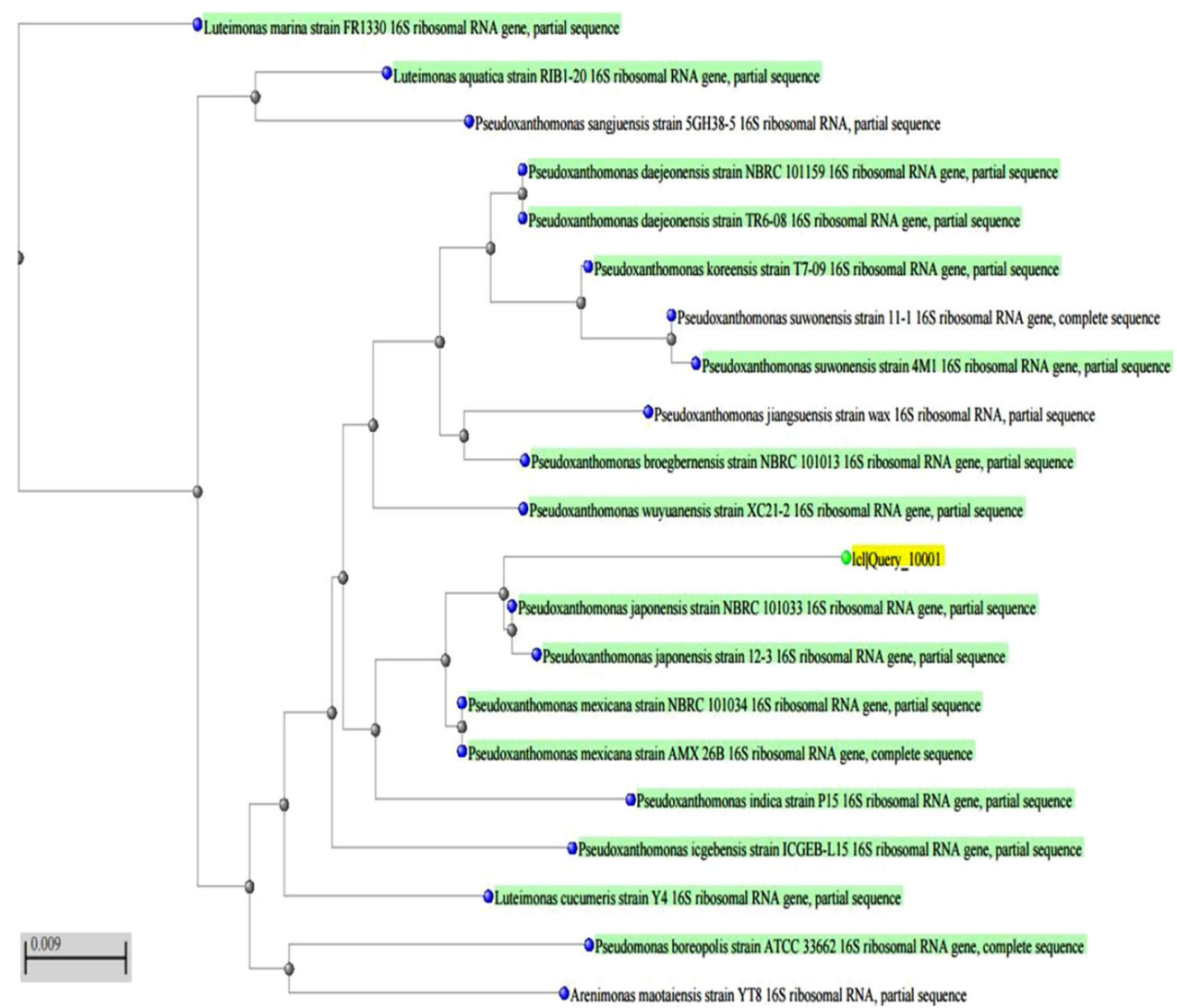

Table 2 Biodegradation of isoproturon by Pseudoxanthomonas sp. at $25^{\circ} \mathrm{C}$ and different $\mathrm{pH}$

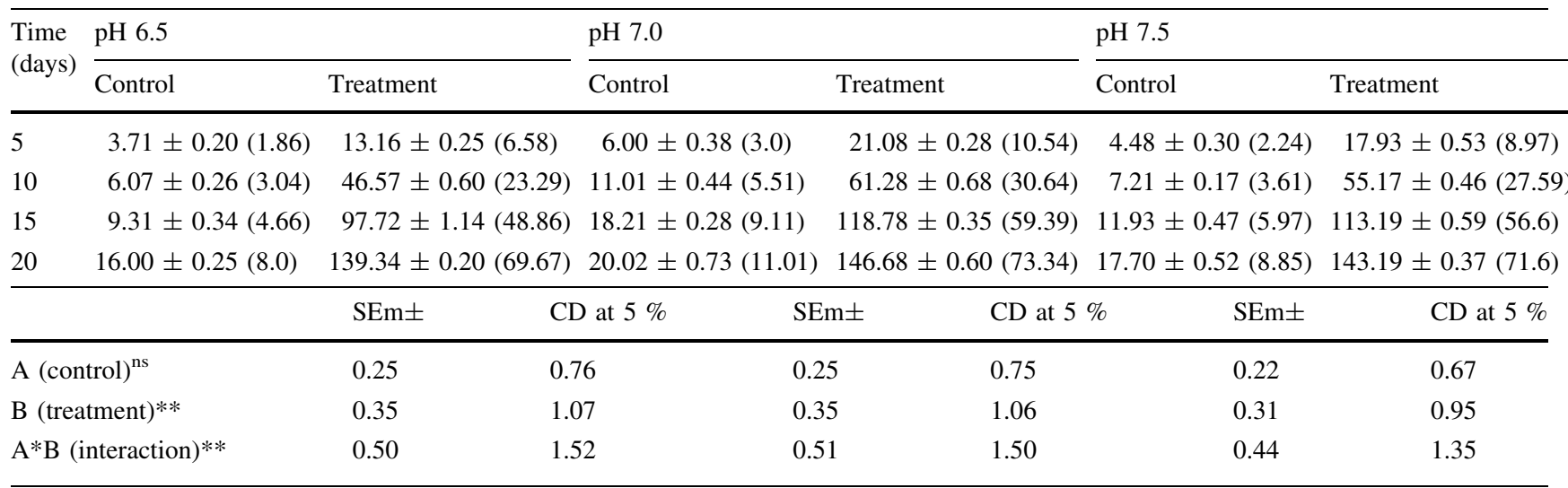

Values are degraded amount of IUP in $\mathrm{mg} \mathrm{l}^{-1}$, initial IPU concentration $=200 \mathrm{mg} \mathrm{l}^{-1}, \pm \mathrm{SE}, n=3$

Values in parenthesis represent \% IPU degradation

Control: uninoculated, Treatment: inoculated with Pseudoxanthomonas sp.

** Significantly different from the control at $p<0.05$

et al. 2004; Sorensen et al. 2001; Widehem et al. 2002), the previous reports together with the present study indicate that different strains belonging to different genera can metabolize IPU. Interestingly, the strains differed in their characteristics of degradation capabilities (Sun et al. 2009). Pesticide degradation potential of the soil micro-flora is greatly subjected to pedoclimatic and physico-chemical conditions of the contaminated environment (Smith et al.
1997; Andrea et al. 2000). Moreover, pH and temperature significantly influence the pesticide-degrading capabilities of microorganisms (Bending et al. 2001, 2003; Walker et al. 2001; Rasmussen et al. 2005). Although the effect of $\mathrm{pH}$ on IPU degradation has also been reported in previous studies (Bending et al. 2003; Hussain et al. 2009, 2011; Sun et al. 2009), but the mechanisms responsible for this regulation have not been explained yet (Sun et al. 2009). The 
Table 3 Biodegradation of isoproturon by Pseudoxanthomonas sp. at $30{ }^{\circ} \mathrm{C}$ and different $\mathrm{pH}$

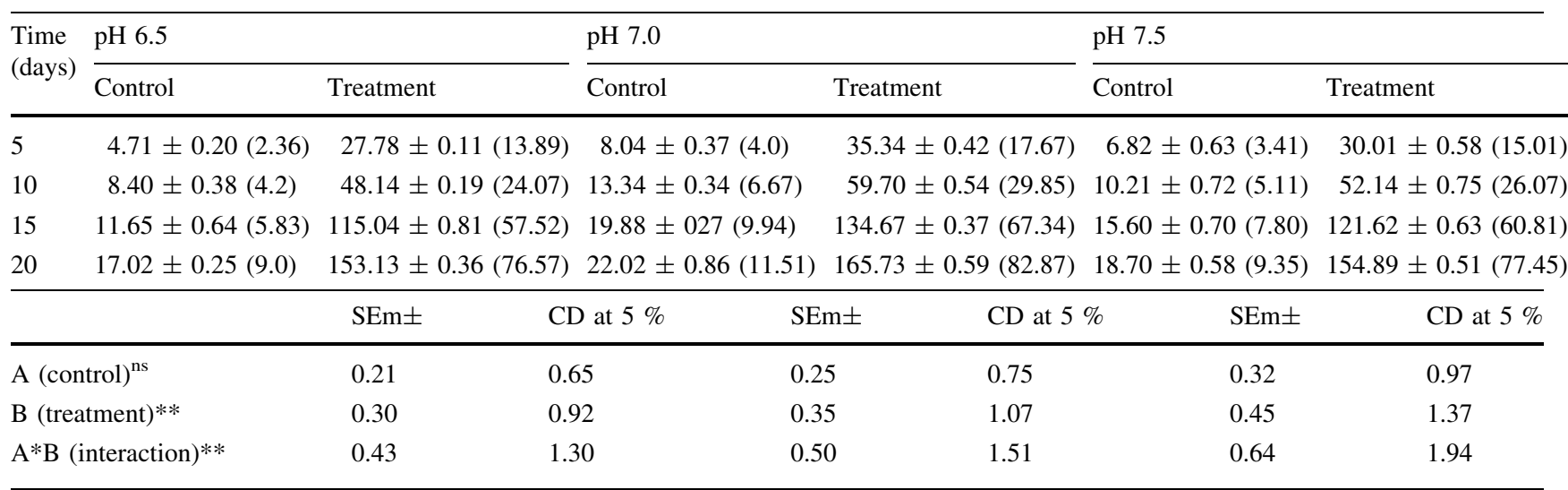

Values are degraded amount of IUP in $\mathrm{mg}^{-1}$, initial IPU concentration $=200 \mathrm{mg}^{-1}$, $\pm \mathrm{SE}, n=3$

Values in parenthesis represent \% IPU degradation

Control: uninoculated, treatment: inoculated with Pseudoxanthomonas sp.

** Significantly different from the control at $p<0.05$

Table 4 Biodegradation of isoproturon by Pseudoxanthomonas sp. at $35^{\circ} \mathrm{C}$ and at different $\mathrm{pH}$

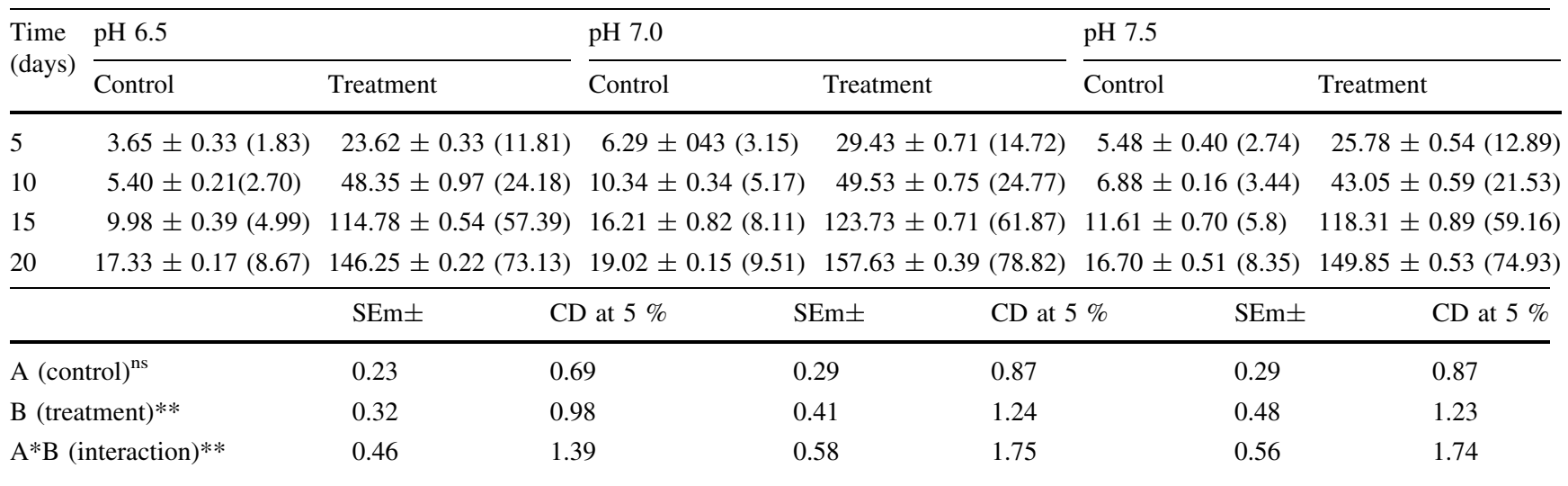

Values are degraded amount of IUP in $\mathrm{mg} 1^{-1}$, initial IPU concentration $=200 \mathrm{mg}^{-1} \pm \mathrm{SE}, n=3$

Values in parenthesis represent \% IPU degradation

Control: uninoculated, treatment: inoculated with Pseudoxanthomonas sp.

** Significantly different from the control at $p<0.05$

$\mathrm{pH}$ is known to affect the growth and survival of microbial populations (Russell and Dombrowski 1980; Sun et al. 1998; Rousk et al. 2009), which ultimately affects their physiological and metabolic activities. The results of the present study indicate that $\mathrm{K} 2$ have the ability to degrade significant quantities of IPU at $\mathrm{pH}$ range of 7.0-7.5 with an optimum activity at $\mathrm{pH} 7.0$ and reduced activity at $\mathrm{pH} 6.5$. This supports the fact that $\mathrm{pH}$ has an effect on the growth or survival of the bacterial population, which explains the variation in IPU degradation rate observed at different $\mathrm{pH}$ values The data recorded over the incubation time revealed that during the first 5-10 days, there was slow biodegradation of IPU, which might represent a lag phase while it got accelerated as the incubation proceeded, most likely due to induction/activation of enzymes in the inoculated cultures (Hussain et al. 2007; Giri et al. 2014). In the present investigation along with $\mathrm{pH}$, temperature has also been observed as a key factor for IPU degradation by K2. Experimental data revealed maximum IPU degradation in $30{ }^{\circ} \mathrm{C}$. It is very likely that $30{ }^{\circ} \mathrm{C}$ might be more conducive to bacterial growth than other incubation temperatures (Hussain et al. 2007).

Temperature plays a key role in bacterial metabolism and slight variation in temperature may increase or decrease the metabolic rates of the microorganisms. Interestingly, among the previously reported metabolites of IPU biodegradation, only 4-isopropylaniline was detected in the medium. The absence of other reported by-products 
Table 5 Concentration of 4-isopropylaniline accumulated in the medium

\begin{tabular}{|c|c|c|c|c|c|c|}
\hline \multirow[t]{2}{*}{ Time (days) } & \multicolumn{2}{|l|}{$\mathrm{pH} 6.5$} & \multicolumn{2}{|l|}{$\mathrm{pH} 7.0$} & \multicolumn{2}{|l|}{ pH 7.5} \\
\hline & Control & Treatment & Control & Treatment & Control & Treatment \\
\hline \multicolumn{7}{|c|}{ Temperature $25^{\circ} \mathrm{C}$} \\
\hline 5 & ND & $0.60 \pm 0.02$ & ND & $0.87 \pm 0.20$ & ND & $0.98 \pm 0.30$ \\
\hline 10 & ND & $2.01 \pm 0.04$ & ND & $2.34 \pm 0.04$ & ND & $1.67 \pm 0.32$ \\
\hline 15 & ND & $3.34 \pm 0.70$ & ND & $3.97 \pm 0.23$ & ND & $2.13 \pm 0.23$ \\
\hline 20 & ND & $3.91 \pm 0.31$ & ND & $4.01 \pm 0.52$ & $1.08 \pm 0.05$ & 2. $76 \pm 1.02$ \\
\hline \multicolumn{7}{|c|}{ Temperature $30^{\circ} \mathrm{C}$} \\
\hline 5 & ND & $0.78 \pm 0.21$ & ND & $1.88 \pm 0.64$ & ND & $2.47 \pm 0.31$ \\
\hline 10 & ND & $2.66 \pm 0.11$ & ND & $3.77 \pm 0.17$ & ND & $3.45 \pm 1.03$ \\
\hline 15 & $0.67 \pm 0.02$ & $3.56 \pm 0.07$ & $0.53 \pm 0.02$ & $4.23 \pm 0.42$ & $1.05 \pm 0.10$ & $3.89 \pm 0.23$ \\
\hline 20 & $0.91 \pm 0.06$ & $4.22 \pm 0.12$ & $1.51 \pm 0.40$ & $4.78 \pm 0.12$ & $1.79 \pm 0.06$ & $4.11 \pm 0.10$ \\
\hline \multicolumn{7}{|c|}{ Temperature $35^{\circ} \mathrm{C}$} \\
\hline 5 & ND & $1.23 \pm 0.05$ & ND & $1.54 \pm 0.32$ & ND & $1.26 \pm 0.17$ \\
\hline 10 & ND & $2.18 \pm 0.21$ & ND & $1.96 \pm 0.16$ & $0.67 \pm 0.14$ & $2.47 \pm 0.10$ \\
\hline 15 & $0.89 \pm 0.12$ & $2.87 \pm 0.51$ & $1.50 \pm 0.21$ & $2.86 \pm 1.20$ & $1.58 \pm 0.23$ & $3.56 \pm 0.26$ \\
\hline 20 & $1.68 \pm 0.31$ & $3.14 \pm 0.13$ & $1.74 \pm 0.07$ & $3.54 \pm 0.32$ & $1.88 \pm 0.21$ & $3.86 \pm 0.17$ \\
\hline
\end{tabular}

Values are presented in $\mathrm{mg}^{-1}, N D$ not detected, $\pm \mathrm{SE}, n=3$

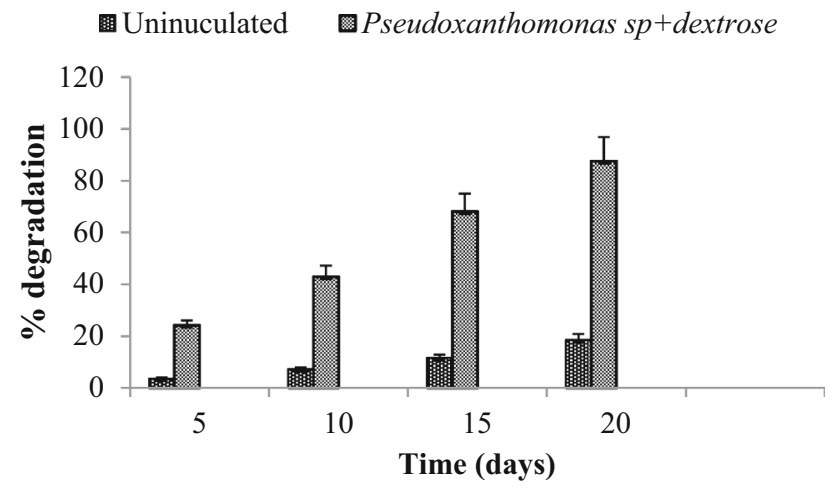

Fig. 2 Biodegradation of isoproturon in the presence of auxiliary carbon source (error bar shows $\pm \mathrm{SE}, n=3$ )

may either be due to their formation below detection limits or simultaneous utilization by the bacterium as a carbon source (Weir et al. 2006).

\section{Effect of supplementary carbon on IPU degradation}

Biodegradation of IPU in the presence of auxiliary carbon source was enhanced significantly as compared to the degradation as sole carbon source. At the end of 5 days, $3.63 \%$ IPU was disappeared from the uninoculated flasks while $24.24 \%$ IPU was utilized by K2. Initially, the degradation of IPU was slow, but it was accelerated between 15 and 20 days. After 20 days of incubation, maximum 87 . $59 \%\left(183.19 \pm 0.94 \mathrm{mg} \mathrm{l}^{-1}\right)$ IPU was mineralized by $\mathrm{K} 2$.
Table 6 Concentration of 4-isopropylaniline accumulated in the medium

\begin{tabular}{lll}
\hline Time (days) & Control & Pseudoxanthomonas sp. + dextrose \\
\hline 5 & ND & $0.78 \pm 0.21$ \\
10 & ND & $1.65 \pm 0.02$ \\
15 & ND & $3.76 \pm 0.33$ \\
20 & $2.07 \pm 0.56$ & $4.03 \pm 0.27$ \\
\hline
\end{tabular}

Values are given in $\mathrm{mg}^{-1}, N D$ not detected, $\pm \mathrm{SE}, n=3$

Statistical analysis confirmed that IPU degradation in both the treatments varied significantly $(P<0.05)$ (Fig. 2). Significant increase in IPU degradation efficiency was observed in cometabolism, where dextrose was added as a supplementary carbon source. About $4.72 \%$ enhancement in IPU degradation was observed due to supplementary carbon source at $\mathrm{pH} 7.0$ and $30{ }^{\circ} \mathrm{C}$ as compared to the treatment without dextrose. 4-isopropylaniline was accumulated as by-product of the IPU degradation in the medium (Table 6).

Addition of auxiliary nutrients stimulates microbial population in the pesticide polluted environment and enhances their catabolic capacities (Scow and Hicks 2005). Comprehensively, biostimulation involves the introduction of adequate amount of nutrients, and oxygen in the medium, to enhance pesticide degradation activity of microbes (Couto et al. 2010) or to promote co-metabolism (De Lorenzo 2008). The concept of biostimulation is to boost the intrinsic degradation potential of a soil micro-flora through the accumulation of amendments, nutrients, or other limiting factors, and has been used for the degradation of wide array of xenobiotics 
(Kadian et al. 2008). Addition of auxiliary carbon to the system having xenobiotic compounds increased the IPU biodegradation potential of bacterial cultures which is often because of increase in metabolic activities of the microbes. Kumar and Philip (2006a) also reported significant increase in endosulfan degradation in the presence of dextrose as a cometabolic reaction in the medium. This particular fact can be attributed to IPU degradation in the present investigation. However, some studies have reported that the addition of auxiliary carbon to the system declined the degradation of pesticide compounds (Awasthi et al. 1997; Kumar and Philip 2006b; Goswami and Singh 2009). This might be because dextrose being an easily available carbon source as compared to pesticide and therefore the bacteria preferred dextrose over xenobiotics as an energy source. The study indicated that during the first 5-10 days, IPU degradation was slow, which can be attributed to a lag phase growth phase. However, it accelerated as the incubation proceeded, most likely due to induction/activation of catabolic enzymes in the inoculated medium (Giri and Rai 2012).

The study established correlation between $\mathrm{pH}$, temperature, effect of auxiliary carbon source and IPU mineralization performance of $\mathrm{K} 2$ under laboratory conditions. These conditions vary from place to place in natural environment; therefore optimization of such factors is crucial while studying the biodegradation of pesticides. The results of this study entail that the enriched soil bacterial isolate possess efficient catalytic capabilities for IPU degradation. Therefore, this bacterial isolate may be useful for bioremediation of pesticide contaminated soil and water environment. However, further research will be needed to study the involvement of different catabolic genes and enzymes in each step of IPU mineralization and its implication in microcosm and field-scale bioremediation studies.

Acknowledgments Technical assistance for HPLC analysis provided by Dr. R.N. Ram, Professor and Head, Department of Fishery Biology, College of Fisheries is gratefully acknowledged.

\section{Compliance with ethical standards}

Conflict of interest The authors declare no conflict of interest.

Open Access This article is distributed under the terms of the Creative Commons Attribution 4.0 International License (http:// creativecommons.org/licenses/by/4.0/), which permits unrestricted use, distribution, and reproduction in any medium, provided you give appropriate credit to the original author(s) and the source, provide a link to the Creative Commons license, and indicate if changes were made.

\section{References}

Andrea MM, Peres TB, Luchini LC, Pettinelli A (2000) Impact of long-term pesticide applications on some soil biological parameters. J Environ Sci Health B 35:297-307
Awasthi N, Manickam N, Kumar A (1997) Biodegradation of endosulfan by a bacterial coculture. Bull Environ Contam Toxicol 59:928-934

Badawi N, Ronhede S, Olsson S, Kragelund BB, Johnsen AH, Jacobsen OS, Aamand J (2009) Metabolites of the phenylurea herbicides chlorotoluron, diuron, isoproturon and linuron produced by the soil fungus Mortierella sp. Environ Pollut 157(10):2806-2812

Behera BC, Bhunya SP (1990) Genotoxic effect of isoproturon (herbicide) as revealed by three mammalian in vivo mutagenic bioassays. Ind J Exp Biol 28(9):862-867

Bending GD, Shaw E, Walker A (2001) Spatial heterogeneity in the metabolism and dynamics of isoproturon degrading microbial communities in soil. Biol Fertil Soils 33:484-489

Bending GD, Lincoln SD, Sorensen SR, Morgan JAW, Aamand J, Walker A (2003) In-field spatial variability in the degradation of the phenyl-urea herbicide isoproturon is the result of interactions between degradative Sphingomonas spp. and soil $\mathrm{pH}$. Appl Environ Microbiol 69(2):827-834

Cosgrove L, McGeechan PL, Handley PS, Robson GD (2010) Effect of biostimulation and bioaugmentation on degradation of polyurethane buried in soil. Appl Environ Microbiol 76(3):810-819

Couto MNPFS, Monteiro E, Vasconcelos MTSD (2010) Mesocosm trials of bioremediation of contaminated soil of a petroleum refinery: comparison of natural attenuation, biostimulation and bioaugmentation. Environ Sci Pollut Res 17(7):1339-1346

De Lorenzo V (2008) Systems biology approaches to bioremediation. Curr Opin Biotechnol 19(6):579-589

Dejonghe W, Berteloot E, Goris J (2003) Synergistic degradation of linuron by a bacterial consortium and isolation of a single linuron-degrading variovorax strain. Appl Environ Microbiol 69:1532-1541

Dwivedi S, Singh BR, Al-Khedhairy AA, Musarrat J (2011) Biodegradation of isoproturon using a novel Pseudomonas aeruginosa strain JS-11 as a multi-functional bioinoculant of environmental significance. J Hazard Mater 185(2-3):938-944

El-Sebai T, Lagacherie B, Soulas G, Martin-Laurent F (2004) Isolation and characterisation of an isoproturon-mineralising Methylopila sp. TES from French agricultural soil. FEMS Microbiol Lett 239(1):103-110

El-Sebai T, Lagacherie B, Cooper JF, Soulas G, Martin-Laurent F (2005) Enhanced isoproturon mineralisation in a clay silt loam agricultural soil. Agron Sustain Dev 25:271-277

El-Sebai T, Lagacherie B, Soulas G, Martin-Laurent F (2007) Spatial variability of isoproturon mineralizing activity within an agricultural field: geostatistical analysis of simple physicochemical and microbiological soil parameters. Environ Pollut 145(3):680-690

Giri K, Rai JPN (2012) Biodegradation of endosulfan isomers in broth culture and soil microcosm by Pseudomonas fluorescens isolated from soil. Int J Environ Stud 69(5):729-774

Giri K, Rawat AP, Rawat M, Rai JPN (2014) Biodegradation of hexachlorocyclohexane by two species of Bacillus Isolated from contaminated soil. Chem Ecol 30(2):97-109

Giri K, Suyal DC, Mishra G, Pandey S, Kumar R, Meena DK, Rai JPN (2015) Biodegradation of Isoproturon by Bacillus pumilus K1 Isolated from Foothill agro-ecosystem of North West Himalaya. Proc Natl Acad Sci India Sect B Biol Sci. doi:10. 1007/s40011-015-0667-x

Goswami S, Singh DK (2009) Biodegradation of $\alpha$ and $\beta$ endosulfan in broth medium and soil microcosm by bacterial strain Bordetella sp. B9. Biodegradation 20:199-207

Hoshiya T, Hasegawa R, Hakoi K, Cui L, Ogiso T, Cabral R, Ito N (1993) Enhancement by non-mutagenic pesticides of GST-P positive hepatic foci development initiated with diethylnitrosamine in the rat. Cancer Lett 72(1-2):59-64 
Hussain S, Arshad M, Saleem M, Khalid A (2007) Biodegradation of $\alpha$ and $\beta$-endosulfan by soil bacteria. Biodegradation 18:731-740

Hussain S, Sorensen SR, Devers-Lamrani M, El-Sebai T, MartinLaurent F (2009) Characterization of an isoproturon mineralizing bacterial culture enriched from a French agricultural soil. Chemosphere 77(8):1052-1059

Hussain S, Devers-Lamrani M, El Azhari N, Martin-Laurent F (2011) Isolation and characterization of an isoproturon mineralizing Sphingomonas sp. strain SH from a French agricultural soil. Biodegradation 22:1637-1650

Kadian N, Gupta A, Satya S, Mehta RK, Malik A (2008) Biodegradation of herbicide (atrazine) in contaminated soil using various bioprocessed materials. Bioresour Technol 99(11):4642-4647

Kanissery RG, Sims GK (2011) Biostimulation for the enhanced degradation of herbicides in soil. Appl Environ Soil Sci 2011:843450. doi: $10.1155 / 2011 / 843450$

Kumar M, Philip L (2006a) Bioremediation of endosulfan contaminated soil and water-optimization of operating conditions in laboratory scale reactors. J Hazard Mat B 136:354-364

Kumar M, Philip L (2006b) Enrichment and isolation of a mixed bacterial culture for complete mineralization of endosulfan. J Environ Sci Health B 41:81-96

Muller K, Bach M, Hartmann H, Spiteller M, Frede HG (2002) Pointand nonpoint-source pesticide contamination in the Zwester Ohm catchment, Germany. J Environ Qual 31(1):309-318

Pieuchot M, Perrin-Garnier C, Portal JM, Schiavon M (1996) Study on the mineralisation and degradation of isoproturon in three soils. Chemosphere 33:467-478

Rasmussen J, Aamand J, Rosenberg P, Jacobsen OS, Sorensen SR (2005) Spatial variability in the mineralisation of the phenylurea herbicide linuron within a Danish agricultural field: multivariate correlation to simple soil parameters. Pest Manag Sci 61:829-837

Rousk J, Brookes PC, Baath E (2009) Contrasting soil pH effects on fungal and bacterial growth suggest functional redundancy in carbon mineralization. Appl Environ Microbiol 75(6):1589-1596

Russell JB, Dombrowski DB (1980) Effect of pH on the efficiency of growth by pure cultures of rumen bacteria in continuous culture. Appl Environ Microbiol 39(3):604-610

Scow KM, Hicks KA (2005) Natural attenuation and enhanced bioremediation of organic contaminants in groundwater. Curr Opin Biotechnol 16(3):246-253
Smith EA, Prues SL, Oehme FW (1997) Environmental degradation of polyacrylamides. 2 Effects of environmental (outdoor) exposure. Ecotoxicol Environ Safe 37:76-91

Sorensen SR, Ronen Z, Aamand J (2001) Isolation from agricultural soil and characterization of a Sphingomonas sp. able to mineralize the phenylurea herbicide isoproturon. Appl Environ Microbiol 67(12):5403-5409

Sorensen SR, Bending GD, Jacobsen CS, Walker A, Aamand J (2003) Microbial degradation of isoproturon and related phenylurea herbicides in and below agricultural field's. FEMS Microbiol Ecol 45:1-11

Spliid NH, Koppen B (1998) Occurrence of pesticides in Danish shallow ground water. Chemosphere 37(7):1307-1316

Sun CQ, O'Connor CJ, Turner SJ, Lewis GD, Stanley RA, Roberton AM (1998) The effect of $\mathrm{pH}$ on the inhibition of bacterial growth by physiological concentrations of butyric acid: implications for neonates fed on suckled milk. Chem Biol Interact 113(2):117-131

Sun JQ, Huang X, Chen QL, Liang B, Qiu JG, Ali SW, Li SP (2009) Isolation and characterization of three Sphingobium sp strains capable of degrading isoproturon and cloning of the catechol 1 , 2-dioxygenase gene from these strains. World J Microbiol Biotechnol 25(2):259-268

Vallotton N, Eggen RIL, Chevre N (2009) Effect of sequential isoproturon pulse exposure on Scenedesmus vacuolatus. Arch Environ Contam Toxicol 56(3):442-449

Walker A, Jurado-Exposito M, Bending GD, Smith VJR (2001) Spatial variability in the degradation rate of isoproturon in soil. Environ Pollut 111:407-415

Weir KM, Sutherland TD, Horne I, Russell RJ, Oakeshott JG (2006) A single monooxygenase, Ese, is involved in the metabolism of the organochlorides endosulfan and endosulfate in an Arthrobacter sp. Appl Environ Microbiol 72:3524-3530

Widehem P, Ait-Aissa S, Tixier C (2002) Isolation, characterization and diuron transformation capacities of a bacterial strain Arthrobacter sp. N2. Chemosphere 46:527-534

Widenfalk A, Bertilsson S, Sundh I, Goedkoop W (2008) Effects of pesticides on community composition and activity of sediment microbes-responses at various levels of microbial community organization. Environ Pollut 152(3):576-584 